\title{
EVASÃO DE DIVISAS: DOS PROCESSOS DE DESCRIMINALIZAÇÃO À PROPOSTA DE PROTEÇÃO PELO DIREITO SANCIONADOR
}

TAX EVASION: FROM THE DECRIMINALIZATION PROCESSES TO A PROTECTION PROPOSAL UNDER SANCTIONING LAW

\author{
Gamil Föppel El Hireche $e^{1}$ \\ Universidade Federal da Bahia \\ Alan Siraisi Fonseca ${ }^{2}$ \\ Universidade Federal da Bahia
}

\section{Resumo}

Este trabalho propõe uma análise sobre o crime de evasão de divisas. Aponta-se, através de uma pesquisa teórica, a discussão sobre a legitimidade da intervenção penal no alcance do tipo incriminador de evasão de dividas, haja vista sua crescente ineficácia, devido às modificações ocorridas entre o contexto econômico que deu origem à sua tipificação e a realidade brasileira atual. Adota-se a premissa de que a existência de normas incriminadoras pressupõe o atendimento de critérios como legalidade, necessidade, adequação e proporcionalidade em sentido estrito. Ocorre que, cada vez mais, reconhece-se a incompatibilidade do crime de evasão de divisas com estes princípios/critérios/máximas. Desse modo, busca-se estabelecer um posicionamento quanto aos consequentes processos de descriminalização da conduta, adequando-a ao contexto atual de proteção do sistema financeiro nacional.

Palavras-chave

Evasão de divisas. Processos de descriminalização. Direito sancionador

1 Professor Direito Penal da Universidade Federal da Bahia. Doutor em Direito Penal Econômico pela Universidade Federal de Pernambuco. Advogado.

${ }^{2}$ Bacharel em Direito pela Universidade Federal da Bahia. Advogado. 


\section{Abstract}

This paper proposes an analysis about the crime of tax evasion. It is pointed out, through a theoretical research, the discussion about the legitimacy of the criminal intervention in achieving the incriminating kind of tax evasion, given its increasing ineffectiveness due to changes occurring between the economic context that gave rise to its definition and the current economic context. The existence of incriminating types requires the attendance criteria such as legality, necessity and appropriateness. Occurs that increasingly recognizes the incompatibility of the crime of tax evasion with these principles Thus, the paper seek to establish parameters that facilitate the interpretation of the studied device, adapting it to the current context of protecting the financial system.

\section{Keywords}

Tax evasion. Decriminalization processes. Sanctioning Law.

\section{INTRODUÇÃO}

O discurso da emergência sempre serviu para legitimar (retoricamente) a criação de normas penais incriminadoras. Afinal, é ínsito ao desenvolvimento (econômico) o surgimento de novos bens jurídicos e, consequentemente, o incremento de riscos sociais, que passam a demandar a intervenção penal, como instrumento fragmentário e subsidiário da política estatal.

Desse modo, o cerceamento de liberdades fundamentais, inerente à criminalização de condutas - tanto em razão da proibição do comportamento pelo tipo penal, quanto decorrente da previsão legislativa da sanção penal -, torna-se justificável e imprescindível à preservação da normalidade e, sobretudo, de respeito à dogmática penal, aos seus pressupostos.

Acontece que as situações de crise passam, a imprescindibilidade da intervenção penal desaparece, sem que as garantias anteriormente tolhidas sejam restabelecidas. Efetivamente, o "legislador caminha sempre com o passo trôpego" (COSTA JR., 1995, p. 11), deixando de prever condutas quando as necessidades se acentuam, mas de igual forma se mantendo inerte no processo de descriminalização que deveria ser superveniente (revogando-se, por exemplo, o tipo penal que fora excepcionalmente editado). Assim, as 
emergências se perenizam na legislação penal. Aliás, a ideia de emergência perpassa há muito tempo o discurso do direito penal econômico:

O estatuto jurídico da emergência faz supor que é sempre necessária uma legislação punitiva dos delitos econômicos quando se produzam situações que alteram a marcha regular do mercado e deve ser assegurada a proteção adicional da livre concorrência como maneira de evitar que certos núcleos econômicos distorçam oferta e procura. ${ }^{3}$

Como metonímia a essa angústia acadêmica, este trabalho buscou investigar o crime de evasão de divisas. Malgrado a recorrência com que o tema vem sendo tratado pela doutrina, ainda há grande descompasso entre a produção teórica e a realidade legislativa e jurisprudencial brasileira, especialmente no que concerne à definição de quais as condutas seriam merecedoras de pena, ante seu potencial lesivo ao Sistema Financeiro Nacional, mais precisamente às reservas cambiais brasileiras, a justificar a escolha do tema, pela sua relevância social.

Em outras palavras, inexistindo expressa revogação pelo legislador, bem como não havendo declaração de não recepção através da correspondente ação de controle abstrato de constitucionalidade perante o Supremo Tribunal Federal, chega-se à problemática de se reconhecer sua inadequação, sem que se prevejam mecanismos que possibilitem ao intérprete afastar sua aplicação em determinado caso concreto.

${ }^{3}$ SANTOS, Gérson Pereira dos. Direito Penal Econômico. São Paulo: Saraiva, 1981, p.93/94. 
Afinal, só se pode deixar de aplicar dispositivo de lei em restritas hipóteses (STRECK, 2010), que exigem um elevado ônus argumentativo do intérprete, nem sempre habilitado ao enfrentamento da questão. Assim, inquéritos continuam a ser instaurados, denúncias permanecem sendo oferecidas e sentenças condenatórias ainda são proferidas, com seus respectivos custos econômicos e sociais, apenas pela persistente previsão legal do tipo penal incriminador, sem que haja maiores reflexões críticas sobre o fato criminalizado.

Com efeito, põe-se a seguinte premissa teórica: a legitimidade da intervenção penal pressupõe, enquanto norma restritiva de direitos fundamentais, além do critério formal da legalidade, a verificação da necessidade, adequação e proporcionalidade em sentido estrito (HIRECHE, 2011), requisitos que aparentemente são desprezados ao se tipificar o crime de evasão de divisas (tal como atualmente disciplinado, tanto na Lei 7.492/86, quanto nos correspondentes diplomas administrativos).

Dessa maneira, afirma-se ser necessário que se proceda a uma interpretação conforme à Constituição ou a declaração parcial da nulidade sem redução de texto, a fim de se preservar a aplicação da norma incriminadora apenas às situações em que houver "correspondência dos comportamentos proibidos e aqueles dotados de relevância econômica, assim aferidos a partir das normas administrativas que regulam a atividade econômica" (BOTTINO, 2013).

Assim sendo, será evidenciado o processo de descriminalização formal, substitutiva e de fato (CERVINI, 1995), por que passou o delito de evasão de divisas ao longo dos trinta anos de vigência da Lei dos Crimes contra o Sistema Financeiro Nacional, propondo possíveis mecanismos de controle fora do âmbito penal. 
1. PROBLEMATIZAÇÃO: A PERENIZAÇÃO DA EMERGÊNCIA NA LEI 7.492/86. NOTAS SOBRE A INCOMPATIBILIDADE DO CRIME DE EVASÃO DE DIVISAS COM A REALIDADE ATUAL.

O Direito Penal, enquanto instrumento de política estatal, é estritamente voltado à proteção de bens jurídicos (SCHÜNEMANN, 2005).

Esta tutela, contudo, não é tautológica, havendo de observar os limites impostos pela dogmática penal (enquanto construção histórica), cujas garantias foram consolidadas (ainda que implicitamente) no texto constitucional, entre as quais a legalidade (aqui entendida em suas três dimensões como taxatividade, anterioridade e reserva legal), intervenção mínima (subsidiariedade e fragmentariedade) e proporcionalidade.

Desse modo, o surgimento de novas necessidades, que reclamam a intervenção do Estado, não legitima por si só a criação de novas figuras penais, à revelia de toda construção teórica que rege esse ramo do direito. Ainda que se busque uma intervenção subsidiária, pautada em um funcionalismo teleológico racional, ainda assim a história do direito penal será marcada pela criação de novos crimes, haja vista que aparecerão novas necessidades que, decisivamente, demandarão novas proteções.

Essa constatação torna-se mais relevante no estudo do crime de evasão de divisas, para o qual a ideia de legislação penal de emergência é fundamental à compreensão da própria existência desta figura típica.

Deveras, a Lei de Crimes Contra o Sistema Financeiro Nacional foi editada em 1986, momento em que o Brasil sofria uma das mais graves das suas crises econômicas e financeiras, período marcado pela criação de sucessivos planos econômicos mal sucedidos. 
Em um dos despautérios econômicos, institui-se a moratória. Sobre o contexto histórico vivido no final da década de 1980, convém transcrever a lição de Carlo Velho Masi (2013, p. 85):

\begin{abstract}
Sinteticamente, o resultado foi uma hiperinflação sem precedentes, que culminou em um ambiente econômico artificial, sem contrapartida de necessária redução de gastos públicos. No mercado interno, os juros reais da economia estavam negativos, algo que desestimulava a poupança e pressionava o consumo, deteriorando a balança de pagamentos do país. Externamente, o país perdeu uma parcela considerável de suas reservas internacionais e, sem poder honrar seus compromissos, teve de decretar a moratória da dívida externa em 1987.A fuga de capitais causava tamanho desequilíbrio à economia nacional, que o governo de então precisou valer-se do Direito Penal para tentar contornar a crise.
\end{abstract}

Lembra, inclusive, que em situação econômica ainda mais grave, o Governo Alemão nazista criou, no ano de 1933, o crime de "traição à economia do povo", que previa a sanção capital àquele que, a qualquer título, remetesse ou mantivesse patrimônio no exterior.

Não se pense que a intervenção penal na economia é um atributo exclusivo do capitalismo. Tal intervenção ocorre sempre que o Estado buscava resguardar e organizar a atividade econômica. Isto não era diferente nos países ditos socialistas. $\mathrm{Na}$ opinião de Miguel Reale Jr., estampando a importância de Marx para o Direito Penal Soviético "A infraestrutura social é constituída pelas relações de produção, sendo o direito expressão do modo pelo qual se estabelece o domínio de uma classe sobre os meios de produção"4 Ora, se a

${ }^{4}$ REALE JR., Miguel. Antijuridicidade Concreta. São Paulo: José Bushatsky, 1974, p.15. 
proteção recai sobre os meios de produção há uma demonstração inequívoca do Direito Penal Econômico na então URSS. Neste país, berço do comunismo mundial, o Direito Penal era usado na economia para reforçar o modelo socialista e afugentar qualquer tentativa de utilização do modelo capitalista. Como bem adverte Luis Luisi, a edição do Código Penal Soviético teve por finalidade sepultar o direito marcado pela burguesia capitalista dominante e fazer aparecer um "direito penal rigorosamente obediente ao pensamento marxista". ${ }^{5}$

Em semelhante contextualização, Thiago Bottino (2013)

afirma:

Na década de 1980, o controle cambial era tema de suma importância para a economia brasileira. O milagre econômico da década anterior alimentara-se de sucessivos empréstimos internacionais, criando dívidas que deveriam ser pagas ou, ao menos, administradas mediante o pagamento dos juros. Paralelamente, as reservas cambiais minguavam à medida em que, ao pagamento dos juros dos empréstimos, somava-se a elevação do preço da principal matérias--primas para o desenvolvimento industrial brasileiro: o petróleo. As crises do petróleo ocorridas em 1973 e 1979 transformaram as divisas (e principalmente o dólar) em um bem escasso e extremamente valioso no Brasil. Importações eram limitadas, remessas de lucros ao exterior proibidas, viagens internacionais um luxo para poucos. Qualquer ação que diminuísse as reservas cambiais brasileiras colocava em risco a possibilidade de pagamento da dívida externa e o custeio da importação de petróleo. A Lei 7.492/1986, promulgada em junho de 1986, antecipou em alguns meses a decretação da moratória (suspensão unilateral do pagamento) da dívida externa brasileira ocorrida em 1987. Naquele contexto,

${ }^{5}$ LUISI, Luiz. Um Direito Penal do Inimigo: O Direito Penal Soviético. In: Direito Penal em Tempos de Crise. Porto Alegre: Livraria do Advogado, 2007, p.117. 
parecia ser muito apropriada a criminalização das condutas de quem retirasse divisas do país fora dos canais autorizados.

O Direito Penal (entendido tanto como ciência dogmática, quanto como direito positivo/legislado) não desconhece que situações excepcionais podem (ou mesmo devem) influenciar na aplicação da lei (vide previsão do artigo $3^{\circ}$ do Código Penal) ${ }^{6}$. De fato, em meio à crise do Sistema Financeiro, a criação de norma que coibisse a saída de divisas do país poderia ser considerada como intervenção legítima e proporcional do Direito Penal na ordem econômica.

A propósito, sobre os aspectos históricos do processo de criminalização da evasão de divisas, demonstrando o porquê de o legislador tipificar apenas a conduta de remeter moedas ou divisas para o exterior, não prevendo sanção penal para sua contraparte, o ingresso desses objetos materiais no território nacional, eis a posição de Raquel Lima Scalcon (2014):

Vivia-se ainda um modelo desenvolvimentista de Estado, com ampla intervenção na economia, a qual era, então, essencialmente fechada. A preocupação fundamental do Governo era com a proteção do mercado interno, mediante substituição de importações. O câmbio, por sua vez, era artificialmente controlado, havendo uma cotação oficial e outra paralela, com assombrosa disparidade. A política econômica e cambial brasileira revelava-se, assim, extremamente refratária a investimentos externos, especialmente em razão das grandes restrições administrativas existentes à saída de divisas do país. Nessa

${ }^{6}$ Pelos limites deste ensaio, não se discorrerá sobre a recepcao ou não deste artigo pela Constituiçao de 1988. 
conjuntura, por que uma empresa estrangeira investiria no Brasil, se seu objetivo principal - o lucro - quase não poderia daqui sair? Não por acaso essa foi justamente a consequência perversa das medidas econômicas adotadas no período: uma intensa escassez de moeda estrangeira, não pela sua excessiva saída, mas sim pelo seu insignificante ingresso. O Brasil, de um lado, praticamente não possuía reservas de divisas; de outro, era devedor de enormes quantias perante organismos internacionais, como o FMI. Natural que, em um contexto de quase insolvência, o país passasse a impor todas as restrições possíveis à saída de divisas. Ora, já que o ingresso era tão diminuto, a questão era manter, em "solo brasileiro", as poucas divisas ainda existentes. Compreensível, pois, que nesse contexto fosse criminalizada apenas a sua saída ou a sua remessa ao exterior, jamais o seu ingresso, o qual era, inclusive, muito desejado. $\mathrm{O}$ desvalor necessário para justificar a criminalização estava então presente apenas naquela conduta, não nesta.

Tratava-se de uma situação de emergência, em que os instrumentos normativos postos não eram suficientes para lidar com a problemática instalada, nos dizeres de Fauzi Hassan Choukr: "colocando em xeque os padrões normais de comportamento e a consequente possibilidade de manutenção das estruturas" (2002, p. 01).

Não se pode perder de vista, contudo, que a realidade econômica brasileira foi substancialmente alterada: houve a abertura da economia brasileira para investimentos internacionais (notadamente a partir do governo Collor), estabilização da moeda com o plano Real (no governo de Itamar Franco), o controle da inflação e equacionamento da dívida externa (tendo o Brasil passado, inclusive, a condição de credor do Fundo Monetário Internacional).

Desse modo, a superação da situação de emergência deveria, por consequência, possibilitar a revisão da criminalização da evasão de divisas, vez que o potencial lesivo da conduta já não 
representaria a mesma ameaça ao Sistema Financeiro Nacional em relação ao momento em que foi inicialmente prevista. Nesse sentido, novamente, Raquel Lima Scalcon (2014):

Vejamos: se antes estávamos diante de uma economia planificada e fechada, hoje é consenso que o Brasil se transformou em uma franca economia de mercado. Se à época a preocupação era tutelar o mercado interno, atualmente não só há um fomento do mercado externo, como também a busca da competitividade no plano internacional é irrecusável em uma economia globalizada. Além disso, medidas cambiais protetivas, como a de taxação artificial do câmbio, não mais se fazem presentes hoje, sendo substituídas (ex.: câmbio flutuante). Finalmente, se à época da criminalização da evasão de divisas o Brasil encontrava-se tecnicamente "falido", uma vez que praticamente sem qualquer reserva de divisas e com enorme dívida externa, hoje o país possui uma mais do que razoável reserva, a qual alcançou patamar superior a 374 bilhões de dólares em maio de 2013. Em síntese, nesses quase 30 anos (1986-2013), a realidade econômica brasileira foi profundamente alterada, mudanças de rumo, essas, provocadas por novas medidas político-econômicas. Tamanha volatilidade, inerente tanto à economia, quanto à política, não consegue ser acompanhada pela legislação penal, necessariamente vagarosa. Como consequência, muitos delitos econômicos, criados à luz de políticas superadas, são herdados e permanecem vagando pela (des)ordem jurídica, mesmo sem qualquer correspondência com a atual realidade econômica. É o caso do delito de evasão de divisas: a ele falta, hoje, uma base "real" e "concreta" que justifique a sua existência. A realidade que lhe dava sentido ficou no passado. O crime, todavia, teimam em manter no presente.

Embora a edição de diplomas administrativos já tenha reduzido o campo de incidência da norma penal em testilha, ainda não se verificou a compatibilização (tanto no campo legislativo, quanto 
jurisprudencial) da figura típica com a realidade atual. Isso porque, factualmente, é inexorável que normas gestadas em regime de exceção conduzam à perda de legitimidade. Veja-se:

A expansão da intervenção penal de forma emergencial, simbólica e atécnica - com frágeis modelos de tipificação leva à sua deslegitimação cotidiana, o que somente poderá ser corrigido com a superação de metodologias e concepções ultrapassadas, inábeis para sua eficaz compreensão e aplicação. ${ }^{7}$

Com efeito, Marina Pinhão Coelho Araújo (2013), analisando o processo legislativo que resultou na promulga da Lei 7.492/86, especialmente a mensagem de veto da Presidência da República, afirma a existência de um defeito congênito no tipo penal incriminador:

É indiscutível que a Lei 7.492/1986 nasceu em meio à grande controvérsia sobre sua efetividade e qualidade das proposições penais. Necessitava o país, naquela década, de regulação ao mercado financeiro, e estas normas penais foram sancionadas pelo então Presidente da República, com a ressalva de que em breve enviaria ao Congresso Nacional um novo projeto aperfeiçoado sobre o tema. Em sua certidão de nascimento foi, portanto, atestado o defeito de fabricação e a carência de novos dispositivos que lhe substituíssem.

Trata-se, na linha do quanto denunciado por Sérgio Moccia (1999), da perenização de emergência, "fenômeno que insinua a incapacidade de lidar com a criminalidade em um ambiente de normalidade, sendo

7 SOUZA, Luciano Anderson de. Expansão do Direito Penal e Globalização. São Paulo: Quartier Latin do Brasil, 2007, p.176. 
necessária a utilização de medidas excepcionais que, com o tempo, acabam por serem definitivamente incorporadas ao arcabouco jurídico."

Assim, pode-se afirmar que a realidade projetada pelo legislador ordinário no ano de 1986, principalmente em relação ao bem jurídico resguardado pela norma penal incriminadora, é completamente distinta do contexto atual, revelando a incompatibilidade do crime de evasão de divisas, por se tratar de medida restritiva de direitos fundamentais (como, v.g., a livre circulação econômica), sem que haja necessidade e adequação na proibição da conduta.

\section{CONCEITOS BÁSICOS VINCULADOS AO PROCESSO DE DESCRIMINALIZAÇÃO.}

\subsection{Descriminalização}

O senso comum acaba por imputar ao conceito de descriminalização carga bastante genérica, lhe sendo atribuída todas as significações associadas à retirada de determinado comportamento do âmbito do Direito Penal, seja pela interferência legislativa (com a revogação do preceito incriminador), seja pela mudança de orientações doutrinárias e jurisprudenciais (como, por exemplo, o reconhecimento genérico da insignificância de determinado comportamento), seja até mesmo com o estabelecimento de disposições administrativas (vide o caso da abolito criminis temporária da posse de arma de fogo de uso permitido), pela perda da eficácia social da norma (como alguns exemplos de crimes contra a dignidade sexual) ou retirada da previsão de sanção penal privativa de liberdade (como se chegou a cogitar do artigo 28 da Lei 11.343/06).

É preciso, contudo, escrutinar essas conceituações.

Nilo Batista (1974), citando Louk Hulsman, afirma que a descriminalização é o ato pelo qual um comportamento, em relação ao qual o sistema punitivo tem competência para aplicar sanções, é colocado fora 
da competência desse sistema, tanto através de um ato legislativo, quanto de um ato interpretativo. Assevera, portanto, que a única distinção entre ambos seria a ideia de segurança jurídica, mais presente no primeiro.

Com efeito, descriminalização é "sinônimo de retirar formalmente ou de fato do âmbito do Direito Penal certas condutas, não graves, que deixam de ser delitivas" (CERVINI, 1995, p. 72). O fenômeno, segundo Raúl Cervini, se manifestaria sob três distintas vertentes.

Há descriminalização formal ou em sentido estrito quando se outorga um total reconhecimento legal ao comportamento descriminalizado. Cita-se, como exemplos, a relação homossexual entre adultos capazes. É preciso, portanto, para que se possa falar em descriminalização formal, que todo o ordenamento jurídico passe a encarar a conduta como plenamente lícita (o adultério, por exemplo, na legislação brasileira, ainda é uma infração aos deveres do casamento).

Fala-se em descriminalização substitutiva quando as penas criminais são substituídas por sanções de outra natureza. É nesse sentido que se inserem as novas manifestações do poder punitivo estatal, tais como o Direito Administrativo Sancionador, Direito da Intervenção, Direito das Contra-Ordenações e Direito Penal de Segunda Velocidade ${ }^{8}$.

A fundamentação teórica de tal movimento, como regra, centra-se na inadequação do tratamento jurídico-penal para tutela do direito fundamental que se busca resguardar do comportamento proibido. Há um reconhecimento da gravidade da intervenção penal, em que a privação da liberdade sempre é um mal subjacente à sanção, de modo que outros ramos da esfera de controle estatal seriam igualmente adequados, mas menos custosos (social e economicamente), seguindo o subcritério da necessidade, no exame da proporcionalidade da restrição de direito fundamental.

Aspecto comum a ambos os fenômenos de descriminalização

8 Propostas de regulação da ordem econômica, em substituição à tutela penal tradicional, cuja abordagem foi melhor desenvolvida em outro trabalho de um dos autores deste texto (HIRECHE, 2011). 
(formal e substitutiva) é a necessidade de reconhecimento legislativo, com a expressa retira do caráter delitivo da conduta (abolito criminis). Como distinção, tem-se a antijuridicidade do comportamento ausente na primeira, mas preservada quanto à segunda, conforme Raúl Cervini (1995, p. 73):

Observamos que tanto na descriminalização stricto sensu como na que chamamos de substitutiva, a conduta deixa de constituir um ilícito penal, mas na primeira variável a solução é mais radical porque significa a eliminação de toda ilicitude, enquanto que na última hipótese (a substituição), embora o comportamento perca a antijuricidade penal, não fica legalizado nem deixa de ser qualificado como antijurídico e indesejável.

Por derradeiro, ocorre a descriminalização de fato quando o sistema penal deixa de funcionar, em que pese ainda possua competência para tutela do comportamento proibido. É dizer, a conduta ainda tem previsão típica, permanecendo ileso o caráter de ilícito penal, estando ausente apenas a aplicação da pena.

Seriam inúmeras as razões para tal fenômeno: a sobrecarga dos agentes envolvidos na persecução penal (autoridade policial, Ministério Público e juiz); o não conhecimento do caráter criminoso de um comportamento ou a perda de reprovação social da conduta (sem a correspondente atuação revogatória do Poder Legislativo); a criação de "subterfúgios para neutralizar os efeitos de uma criminalização forçada on legitimadora".

Como um aspecto geral, segundo o Comitê Europeu sobre Problemas de Criminalidade, "consiste no fenômeno de redução (gradual) das

${ }^{9}$ Sobre o tema, indicando a ineficácia da Lei dos Crimes Contra o Sistema Financeiro, cf. CASTILHO, 1996. 
atividades do sistema de justiça penal diante de certas formas de comportamento ou de certas situações, desde que não tenha havido mudanças na competência formal do sistema" (CERVINI, 1995, p. 75).

Haveria, nesse sentido, um processo natural de descriminalização, em que o sistema penal deixaria de funcionar, para que posteriormente o legislador, reconhecendo tal circunstância, retirasse sua competência para tutela do comportamento, seja legalizando-o plenamente, seja impondo sanção alternativa à pena (em sentido lato).

A interface de cada um desses fenômenos com o crime de evasão de divisas será objeto de análise individualizada a seguir.

\subsection{Despenalização}

Há uma justificável confusão terminológica entre descriminalização e despenalização, decorrente da correlação que se faz entre o crime e a pena.

Ante a prática criminosa indicar, ao menos teoricamente, a aplicação de uma pena, os movimentos tendentes à abolição do primeiro, invariavelmente, afetarão a noção que se tem da segunda.

A questão reveste-se de ainda maior dificuldade nos processos de descriminalização de fato, quando permanece ilesa a competência do sistema penal e, consequentemente, a previsão típica da conduta, sem que haja a aplicação da sanção penal (por diversas razões e formas).

No entanto, Raúl Cervini (1995, p. 75) reduz a possível amplitude do conceito para abarcar, tão-somente, o ato de diminuir a pena de um delito sem descriminalizá-lo, quer dizer, sem tirar do fato o caráter de ilícito penal.

Foi exatamente essa concepção que levou o Supremo Tribunal Federal a decidir que não houve descriminalização da posse de droga para consumo pessoal, mas apenas despenalização ${ }^{10}$.

10 BRASIL, Supremo Tribunal Federal, Questão de Ordem no Recurso Extraordinário 430.105, Relator Ministro Sepúlveda Pertence, Primeira Turma, julgado em 13/02/2007, publicado no Diário de Justiça em 27/04/2007. Disponível em: 
Em que pese a relevância teórica de se realizar um estudo propositivo sobre a despenalização do crime de evasão de divisas, inclusive pela já verificada desproporcionalidade da sanção cominada (reclusão de dois a seis anos), o tema não será objeto de análise nessa investigação.

\subsection{Diversificação}

Por fim, o conceito de diversificação significa a suspensão dos procedimentos criminais em casos em que o sistema de justiça penal mantém formalmente sua competência, especialmente pela aposta em resoluções consensuais do conflito (no caso da conciliação nos juizados especiais criminais, em tese, persistiria um órgão de persecução penal).

Com premissas teóricas muito similares à descriminalização substitutiva, porém sem a retirada formal do âmbito do Direito Penal dessas condutas, busca-se outras instâncias de controle não pertencentes aos sistemas penais ordinários.

Assim como a despenalização, a questão não será objeto do presente estudo, eis que a natureza difusa/vaga do bem jurídica exigiria análise mais acurada da possibilidade de resoluções consensuais do conflito.

3. OBSTÁCULOS QUE SE APRESENTAM AOS PROCESSOS DE DESCRIMINALIZAÇÃO DA EVASÃO DE DIVISAS.

Ao longo da presente investigação, como fio condutor da pesquisa, verificou-se a paulatina dicotomia entre o plano normativo

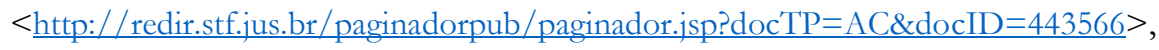
acesso em 13 de maio de 2016. 
(leis e normas administrativas complementares) e o plano fático (a política econômica na gestão e controle das reservas cambiais) em relação ao crime de evasão de divisas.

Buscou-se analisar, inicialmente, a adequação do tratamento jurídico-penal conferido ao tipo penal incriminador, especialmente quanto à descrição da conduta incriminada (estruturada em elementos normativos e normas penais em branco) e a lesividade do comportamento (vez que, isoladamente considerado, não representa dano ou perigo ao bem jurídico que se busca resguardar, somente ganhando relevância com a prática reiterada por diversas pessoas). Nesse sentido, cogitou-se a descriminalização da conduta.

Nesse momento, deve-se apontar as principais dificuldades que se apresentam a esse (já ocorrente) processo de descriminalização, classificadas em fatores sociais, de tipo legal e de política criminal.

Em texto sobre o impacto da atuação da mídia na criminalização da evasão de divisas, especialmente sobre a criação de um estereótipo associado ao "criminoso de colarinho branco", Rafael Lira (2011) demonstra que desde o projeto de lei 273/1983, da autoria do Deputado Federal Nilson Gibson, a opinião pública é usada como justificativa expressa para a criminalização das condutas praticadas contra o sistema financeiro nacional. Somente para que se deixe claro: reconhece-se a opinião pública (ou publicada) como um fator real de poder de pressão, mas não que qualquer norma penal se legitime em decorrência da vox Populi, mormente quando o direito - e a dogmática penal em particular - cumpre a função contra majoritária.

É até intuitivo que a opinião pública represente um obstáculo ao processo de descriminalização. $O$, muitas vezes irrefletido, discurso de impunidade acaba por influenciar a tomada de 
decisões no Congresso, que se vê acuado em adotar qualquer medida tendente à revogação de tipos penais incriminadores.

Evidentemente, construiu-se uma noção no senso comum de que a conduta relativa à evasão de divisas sempre estaria ligada a outros crimes, mais graves. O imaginário popular passou a associar a saída de divisas para o exterior ou a manutenção de depósitos em países estrangeiros como forma de ocultamento de valores ilícitos, comumente derivados de escândalos de corrupção.

Assim, eventual derrogação do artigo 22, caput e parágrafo único, poderia repercutir no ideário social de modo absolutamente negativo, ainda que não representasse efetiva descriminalização quanto às condutas associadas à evasão de divisas.

Aparenta também ser esse o empecilho ao processo de descriminalização no plano da política criminal (a associação com outros crimes). A esse respeito, Raúl Cervini (1995, p. 75):

Em certos casos, a necessidade de combater eficazmente certas condutas altamente anti-sociais e indesejáveis requer incluir na proibição outras condutas, que em si mesmas não apresentam o mesmo grau de indesejabilidade. Essa pretensa extensão da "linha de defesa" é sumamente perigosa, pois permite que o Direito Penal alcance comportamentos mais ou menos inofensivos ou que não estejam dentro da competência do Estado, afetando claramente a liberdade com o pretexto de uma maior eficiência.

Em dissertação apresentada ao programa de pósgraduação em sociologia da Universidade Federal do Rio Grande do Sul, José Vicente Tavares Santos (2010) analisa a evasão de divisas como uma estratégia do crime organizado. A pesquisa foi desenvolvida com base em acórdãos preferidos pelo Tribunal 
Regional Federal da $4^{a}$ Região, em elogiável e rara análise empírica de um tipo penal.

Nesse sentido, verificou-se a recorrência com que o crime de evasão de divisas era praticado em conjunto com outra figura típica. Das 124 (cento e vinte e quatro) decisões objetos da análise, em 33\% (trinta e três por cento) houve tais concursos de infrações penais, cujas ocorrências foram registradas na seguinte tabela:

\begin{tabular}{|c|c|c|}
\hline \multicolumn{2}{|l|}{ Delitos relacionados } & $\mathbf{N}^{\circ}$ de ementas \\
\hline \multicolumn{2}{|c|}{ Crime contra ordem tributária } & 6 \\
\hline \multicolumn{2}{|l|}{ Lavagem de dinheiro } & 16 \\
\hline \multicolumn{2}{|l|}{ Corrupção } & 2 \\
\hline \multicolumn{2}{|c|}{ Organização Criminosa/Quadrilha/Bando/Associação } & 13 \\
\hline \multirow{5}{*}{$\begin{array}{l}\text { Crimes contra o Sistema Financeiro } \\
\text { Nacional diverso da Evasão de Divisas }\end{array}$} & Art. $4^{\circ}$ & 6 \\
\hline & Art. $6^{\circ}$ & 15 \\
\hline & Art. 10 & 0 \\
\hline & Art. 11 & 4 \\
\hline & Art. 16 & 10 \\
\hline \multicolumn{2}{|l|}{ Descaminho/contrabando } & 4 \\
\hline
\end{tabular}

A análise realizada, contudo, não pode ser facilmente extrapolada para as conclusões indicadas na pesquisa, seja pelo universo demasiadamente pequeno de dados coletados, seja pela evidente desconsideração de variáveis importantes. Como exemplo, não se delimitou as modalidades de concursos de crimes, nem em que 
contexto as infrações foram conjuntamente julgadas, o que torna cientificamente inviável a pretendida relação de causalidade entre a criminalização da evasão de divisas com a maior eficiência na repressão aos crimes a ela associados.

Ainda assim, mesmo desconsiderando essas questões, a criminalização de uma conduta não parece ser um mecanismo idôneo para prevenção de outro delito, ante a vedação à dupla imputação por um mesmo fato (ne bis in idem).

\section{4. É POSSÍVEL DESCRIMINALIZAR A EVASÃO DE DIVISAS? EM QUE TERMOS?}

\subsection{Há diferenças ônticas entre crime e infração administrativa?}

A existência de distinção ontológica entre delito e infração administrativa é uma questão prejudicial ao exame das possibilidades de descriminalização. Nesse sentido, Ana Carolina Carlos de Oliveira (2013, p. 116) faz um relevante estudo sobre as diferenças entre os injustos penal e administrativo.

A autora aponta que, historicamente, as teses diferenciadoras teriam sua origem nas construções de Feuerbach, afirmando que este recorria ao argumento de que os delitos seriam violações a direitos naturais da vítima, enquanto as infrações administrativas representavam afronta ao poder de polícia do Estado.

Desse modo, haveria uma tentativa de estabelecer parâmetros ontológicos de diferenciação a partir de "critérios de danos ou ameaça de dano aos direitos dos cidadãos, contrapostos a regras de administração da sociedade pelo Estado".

$\mathrm{Na}$ continuidade do desenvolvimento desta distinção, assinala que foi James Goldschmidt quem buscou uma posição mais clara (e, consequentemente, ainda hoje ecoante na doutrina). Com efeito, a diferença 
entre ambos os injustos estaria na existência de um desvalor ético, somente presente nos ilícitos penais, que assim permitiria a previsão abstrata de uma pena restritiva de liberdade. De outro lado, segundo sustenta, as sanções administrativas estariam baseadas em "infrações de mera ordenação, eticamente neutras, voltadas para a proteção das estruturas do Estado". Apresenta, desse modo, a categorização [posteriormente suscitada por José Maria Silva Sanchéz (2012), embora não integralmente] de que os delitos seriam mala in se, e as infrações administrativas seriam uma espécie de mala in quia probibita (com todas as consequências dessa classificação, brevemente tratadas no capítulo primeiro).

Essa diferenciação de cunho ético veio a ser posteriormente criticada. Haveria, afinal, delitos que não são necessariamente objetos de intensa reprovação (cita, a propósito, o crime de posse de arma de fogo de uso permitido), enquanto há infrações administrativas com grande desvalor social (como diversas infrações às normas de trânsito, ainda não criminalizadas).

Outrossim, também ocorre uma paulatina proximidade entre os dois grupos de infrações/injustos quanto às suas respectivas consequências jurídicas.

Excluindo-se crimes para os quais é aplicada in concreto pena privativa de liberdade, comparando-se apenas com as penas restritivas de direitos e multas (que possuem certa predominância nos crimes contra a ordem econômica), sanções administrativas podem ter igual ou até maior gravidade.

Nesse sentido, pode-se verificar as sanções previstas na Lei de Improbidade Administrativa $^{11}$ ou na Lei Anticorrupção Empresarial ${ }^{12}$, que

11 BRASIL, Lei n. 8.429, de 2 de junho de 1992. Disponível em: <http://www.planalto.gov.br/ccivil 03/leis/L8429.htm>, acesso em 19 de maio de 2016. 12 BRASIL, Lei n. 12.846, de $1^{\circ}$ de agosto de 2013. Disponível em: <http://www.planalto.gov.br/ccivil 03/ ato2011-2014/2013/lei/112846.htm>, acesso em 19 de maio de 2016. 
preveem consequências jurídicas como o ressarcimento integral do dano, perda dos bens ou valores acrescidos ilicitamente ao patrimônio, perda da função pública, suspensão dos direitos políticos, pagamento de multa civil e proibição de contratar com o Poder Público.

Ademais, não se pode desconsiderar que o campo da ilicitude, em sendo uma construção jurídica, ganha concretude apenas a partir de uma atuação criadora normativa. Daí seria inadequada a busca de distinções ontológicas, exatamente por crime e infração administrativa não serem realidades preexistentes ao Direito.

Ainda assim, mesmo que se considere uma paulatina indistinção, não se pode ignorar dados quantitativos que separam as ideias de crime e injusto administrativo (OLIVEIRA, 2013, p. 123):

Porém, o que enfatiza o autor é que, independentemente de haver ou não uma diferença substancial entre os injustos administrativos e penal, o foco deve ser voltado para a quantidade de sanção, pois não se questiona que uma longa pena de prisão seja mais grave que uma alta multa administrativa. Aqui residiria a diferença qualitativa que aponta Roxin: não a partir do pressuposto do injusto (reprovação ética), mas a partir da quantidade de pena, cuja gravidade é capaz de estabelecer concretamente a diferenciação qualitativa que postulava a doutrina de Goldschmidt.

Não apenas o caráter sancionatório representa um elemento importante de distinção, mas aspectos qualitativos da intervenção penal, inerentes ao processo, tais como estigma moral e reprovação social, demonstram a existência de possíveis critérios diferenciadores.

Desse modo, com essas exatas premissas, Silva Sanchéz aponta um óbice ao processo de descriminalização de condutas, afirmando que as funções de prevenção geral e especial próprias do Direito Penal representariam fator relevante para definição do modelo de intervenção estatal na proteção de bens jurídicos. 
Sendo assim, ressalvando-se os pontos extremos, em que se aplica pena privativa de liberdade, haveria uma margem de liberdade para o legislador definir a tutela a ser empregada (administrativa ou criminal).

Todas essas posições, contudo, desconsideram fator de extrema relevância. A partir da escolha do instrumento de proteção a bens jurídicos, estabelecem-se distintas garantias.

A partir do momento em que se decide criminalizar a conduta, passa-se a exigir uma taxativa definição do comportamento proibido; as regras de persecução estatal são estritas, pressupondo um processo judicial, em que se garanta contraditório, ampla defesa, duplo grau de jurisdição, não se podendo estabelecer presunções desfavoráveis ao agente; critérios de imputação são rigorosos e restritivos; o elemento subjetivo, em regra, exige demonstração de vontade e consciência em praticar o ilícito.

Com efeito, a margem de liberdade que o legislador teria na definição da forma de intervenção estatal, não só necessita da consideração de fatores atinentes à sanção penal (e suas funções de prevenção), como a pertinência da norma de proibição de conduta com os princípios reitores do Direito e Processo penal.

\subsection{A descriminalização substitutiva da evasão de divisas: o direito administrativo sancionador no controle da política cambial brasileira.}

Ao longo da pesquisa, pôde-se constatar o descompasso da persistente criminalização da evasão

de divisas com a realidade econômica atual. Verificou-se, então, a paulatina perda de eficácia da norma, com significativa redução do seu âmbito de incidência, seja através de normas administrativas (como a ampliação dos valores para os quais torna-se desnecessária a declaração de depósitos mantidos no exterior), seja através de determinadas interpretações doutrinárias e jurisprudenciais, como as relativas aos diversos elementos normativos do tipo penal incriminador (v.g., operação de câmbio não 
autorizada, autorização legal; saída de moedas e divisas para o exterior).

Ainda assim, a exigência constitucional de se administrar as reservas cambiais do País e fiscalizar as operações de natureza financeira, torna inócua uma discussão sobre a descriminalização formal das condutas típicas referentes à evasão de divisas. Isto porque, enquanto houver regulação estatal, mandamento constitucional indissociável ao sistema financeiro nacional, sempre haverá um âmbito de ilicitude.

Andrei Zenkner Schmidt e Luciano Feldens (2011), inclusive, apontam o ilícito administrativo como elemento pressuposto à configuração do delito cambial:

Nesses termos, lançamos nossa observação conclusiva, a partir da qual problematizaremos as situações a seguir expostas: na espécie estudada, ilícito administrativo e ilícito penal formam dois círculos concêntricos, sendo o âmbito da esfera jurídico-penal o de menor diâmetro. Em resumo: o ilícito penal tem como pressuposto necessária, porém insuficiente, a prévia verificação do ilícito administrativo (violação à regra cambial).

Ocorre que, ao se manter a tutela no âmbito criminal, longe de existir uma efetiva função de prevenção geral ou especial, criam-se diversos empecilhos à atividade persecutória do Estado, que passa a ter de observar diversas garantias ínsitas ao processo penal, consequência decorrente da previsão de sanção privativa de liberdade.

Com efeito, seguindo essa lógica, Miguel Reale Júnior (1999) propõe uma terceira via de controle estatal, com a adoção de alguns princípios do Direito Penal no campo do ilícito administrativo:

A formulação de uma "terceira via", caminho a percorrer-se entre a trilha rígida do direito penal e a maior fluidez do direito administrativo está na mente de autores do peso de Hassemer que preconiza ser preciso pensar um novo campo do direito que "não aplique as pesadas sanções do Direito Penal, sobretudo as sanções de privação da liberdade e que, 
ao mesmo tempo possa ter garantias menores". O autor chama este novo campo de "Direito de Intervenção". A seu ver - em perspectiva que endossamos - o Direito Penal deveria ter por fulcro a proteção de bens individuais, como a vida, a liberdade, a integridade física e a propriedade, sem se voltar para o campo da moderna criminalidade. Do contrário, a seu ver, arrebentar-se-á o Direito Penal, que se transforma em um instrumento ineficiente.

Os questionamentos acerca da legitimidade da intervenção penal na política cambial, com a criminalização da evasão de divisas, centram-se nas dificuldades sobre a descrição do fato típico (com a utilização de elementos normativos do tipo e normas penais em branco) e na potencialidade lesiva do comportamento proibido, que aparentam ser incompatíveis com os princípios penais da taxatividade e lesividade/ofensividade, problema que, inclusive, não é exclusivo do crime de evasão de divisas, mas o verdadeiro ponto nevrálgico da intervenção penal na economia: a questão de legitimidade do emprego da dogmática penal tradicional.

Ocorre que, caso se entendesse pela aplicação do direito administrativo sancionador, em substituição à tutela penal, essas aporias poderiam ser superadas. Isto porque, conforme já abordado em outra oportunidade (HIRECHE, 2011), ao não adotar a pena privativa de liberdade como alternativa sancionadora, o Direito Sancionador comportaria menos garantias que o Direito Penal, destacadamente a taxatividade e a jurisdicionalidade.

Acrescente-se a essa plêiade o princípio da lesividade. Não que o Direito Administrativo Sancionador, necessariamente, se importe com violações de bagatela (a proporcionalidade, nesse cenário, seria um filtro adequado à solução do problema). É que, se no Direito Penal a violação a normas de controle estatal (poder de polícia) configurar-se-ia ilegítima, esse tipo de tutela é próprio do Direito Administrativo. Desse modo, superamse as dificuldades da lógica dos delitos por acumulação: a ofensa não seria 
mais sobre o bem jurídico (reservas cambiais), mas sobre a própria política cambiária brasileira.

\section{CONSIDERAÇÕES FINAIS}

Diante de tudo quanto o exposto, pôde-se constatar que:

a. Em razão da criação de novos riscos sociais, mormente os decorrentes de avanços tecnológicos e culturais, passou-se a exigir a expansão do Direito Penal para novas fronteiras, principalmente para proteção de bens jurídicos vinculados à ordem econômica;

b. A realidade projetada pelo legislador ordinário no ano de 1986, principalmente em relação ao bem jurídico resguardado pela norma penal incriminadora, é completamente distinta do contexto atual, revelando que o crime de evasão de divisas, por se tratar de medida restritiva de direitos fundamentais (como, v.g., a livre circulação econômica), sem que haja (pelo menos não com a mesma intensidade) necessidade na proibição da conduta, é exemplo de legislação penal de emergência que se perenizou;

c. Assim, ante alteração da conjuntura econômica entre o momento em que a Lei de Crimes Contra o Sistema Financeiro Nacional foi editada e a realidade atual, emerge a necessidade de se criarem novos parâmetros interpretação da norma penal em estudo, seja pela aplicação dos mecanismos de interpretação conforme à Constituição e nulidade parcial sem redução de texto, seja pela incidência de princípios penais (notadamente, proporcionalidade e adequação social), que afastem a aplicação da figura típica (cuja estrutura normativa é de uma regra) em determinados casos concretos;

d. Os obstáculos aos processos de descriminalização da evasão de divisas centram-se nos possíveis reflexos da eventual abolitio criminis para persecução penal em relação a outros comportamentos, principalmente a lavagem de dinheiro e a sonegação fiscal;

e. Como proposta a essa reconhecida incompatibilidade na 
criminalização da evasão de divisas, aponta-se a via do Direito Administrativo Sancionador que, ante as diferentes alternativas sancionatórias, permite a renúncia de determinadas garantias, tornando a intervenção penal, em relação às condutas criminalizadas na evasão de divisas, mais eficiente.

\section{REFERÊNCIAS}

ALEXY, Robert. Teoria dos direitos fundamentais. 2. ed. Tradução de Virgílio Afonso da Silva. São Paulo: Malheiros, 2011.

ARAÚJO, Fábio Roque. O princípio da proporcionalidade referido ao legislador penal. Salvador: JusPodivm, 2011.

ARAÚJO JÚNIOR, João Marcello de. Os crimes contra o sistema financeiro no esboço de nova parte especial do Código Penal de 1994. Revista Brasileira de Ciências Criminais, São Paulo, vol. 11, vol.3, p. 145165, jul./set., 1995.

ARAÚJO, Eugênio Rosa de. Finanças públicas e Direito Penal: o conceito de evasão de divisas no parágrafo único do artigo 22 da Lei no 7.492/1986. Revista da Seção Judiciária do Rio de Janeiro, Rio de Janeiro, v. 19, n. 33, p. 89-96, abr., 2012.

ARAÚJO, Marina Pinhão Coelho. O crime de evasão de divisas e a relevância penal da manutenção de valores no exterior. Boletim IBCCRIM, São Paulo, n. 242, v. 21, p. 14-15, jan., 2013.

ARAÚJO JUNIOR, João Marcello. O direito penal econômico. Revista Brasileira de Ciências Criminais, São Paulo, vol. 25, p.142-155, jan., 1999. 
BARBOZA JÚNIOR, José Cláudio Marques. Evasão de divisas ou crime tributário? Revista Tributária e de Finanças Públicas, São Paulo, vol. 79, p. 212-216, mar./abr., 2008.

BATISTA, Nilo. Consumação e tentativa no crime de evasão de divisas. In: SHECAIRA, Sérgio Salomão (Org.). Estudos criminais em homenagem a Evandro Lins e Silva: criminalista do século. São Paulo: Método, 2001.

. Algumas palavras sobre descriminalização. Revista de Direito Penal, Rio de Janeiro, n. 13, p. 28-40, jan./jun., 1974.

BETANHO, Luiz Carlos. Crimes contra o sistema financeiro nacional. Revista Brasileira de Ciências Criminais, São Paulo, vol. 11, p. 341-345, jul./set., 1995.

BITENCOURT, Cezar Roberto; BREDA, Juliano. Crimes contra o sistema financeiro nacional e contra o mercado de capitais. 3. ed. São Paulo: Saraiva, 2014.

BOTTINO, Thiago. Regulação econômica e Direito Penal econômico: eficácia e desencontro no crime de evasão de divisas. Revista Brasileira de Ciências Criminais, São Paulo, vol. 101, p. 125-153, mar./abr., 2013.

BOZZA, Fábio da Silva. Bem jurídico e proibição de excesso como limites à expansão penal. 2014, 317 f., Tese (Doutorado em Direito do Estado) Faculdade de Direito, Universidade Federal do Paraná, Curitiba, 2014.

CASTILHO, Ela Wiecko Volkmer de. O controle penal nos crimes contra o sistema financeiro nacional (Lei n. 7.492, de 16.06.1986). 1996, 467 f., Tese (Doutorado em Direito) - Faculdade de Direito, Universidade Federal de Santa Catarina, Florianópolis, 1996. 
CATAPANI, Márcio Ferro. Apontamentos sobre o crime de manutenção de depósitos no exterior sem declaração às autoridades brasileiras. Revista Brasileira de Ciências Criminais, São Paulo, vol. 102, p. 221-239, mai./jun., 2013.

CAVALI, Marcelo Costenaro. Exame do crime de manutenção de depósitos não declarados no exterior na APN 470. Revista Brasileira de Ciências Criminais, São Paulo, vol. 106, v. 22, p. 231-250, jan./mar., 2014.

CERVINI, Raúl. Os processos de descriminalização. Tradução de Eliana Granja. São Paulo: Revista dos Tribunais, 1995.

CHOUKR, Fauzi Hassan. Processo Penal de Emergência. Rio de Janeiro: Lumen Juris, 2002.

COSTA JUNIOR, Paulo José da. O direito de estar só: Tutela penal da intimidade. 2. ed. São Paulo: Revista dos Tribunais, 1995.

CRUZ, Flavio Antonio da. Gestão temerária, evasão de divisas e aporias. Revista Brasileira de Ciências Criminais, São Paulo, vol. 86, p. 99-147, set./out., 2010.

D’AVILA, Fábio Roberto. Aproximações à teoria da exclusiva proteção de bens jurídicos no Direito Penal contemporâneo. Revista Brasileira de Ciências Criminais, São Paulo, vol. 80, p. 7-34, set./out., 2009.

DELMANTO JÚNIOR, Roberto. Manutenção de conta bancária no exterior e o crime do art. 22, parágrafo único, in fine, da Lei 7.492/86. Revista dos Tribunais, São Paulo, vol. 855, p. 473-481, jan., 2007.

FELDENS, Luciano; SCHMIDT, Andrei Zenkner. A associação entre o ilícito administrativo e o ilícito penal no exemplo do crime de evasão de divisas. In: PAULA, Marco Aurélio Borges de; MAGRINI, Rachel de Paula 
(Coord.). Estudos de direito público. Campo Grande: Cepejus, 2009.

FELIX, Yuri. Evasão de divisas: breves considerações à luz da política cambial brasileira. In: FRANCO, Alberto Silva; LIRA, Rafael de Souza (Coord.). Direito Penal econômico: questões atuais. São Paulo: Revista dos Tribunais, 2011.

FERNANDES, José Ricardo. A evasão de divisas como estratégia do crime organizado? Razões e consequências dessa criminalização. 2010, 215 f., Dissertação (Mestrado em Sociologia) - Instituto de Filosofia e Ciências Humanas, Universidade Federal do Rio Grande do Sul, Porto Alegre, 2010.

FONTELES, Cláudio. O parágrafo único do art. 22 da Lei 7.492/86: Considerações. Revista dos Tribunais, São Paulo, vol. 860, p. 11-17, jun., 2007.

FORNAZARI JUNIOR, Milton. A legitimidade do crime de evasão de divisas como norma penal em branco e sua legislação integradora. Revista Criminal: ensaios sobre a atividade policial, São Paulo, v. 2, n. 4, p.181-206, jul./set., 2008.

- Aspectos atuais do crime de evasão de divisas. Revista Criminal: ensaios sobre a atividade policial, São Paulo, v. 1, n. 1, p.101-112, out./dez., 2007.

HIRECHE, Gamil Föppel El. A (i)legitimidade da tutela penal da ordem econômica: simbolismo, ineficiência e desnecessidade do Direito Penal econômico. 2011, 442 f. Tese (Doutorado em Direito) - Faculdade de Direito, Universidade Federal de Pernambuco. Recife, 2011.

LIRA, Rafael de Souza. O crime de evasão de divisas: análise crítica sobre a atuação da mídia nos processos pré e pós-legislativo: comentários sobre a (des)necessidade da tutela penal. In: FRANCO, Alberto Silva; LIRA, Rafael 
de Souza (Coord.). Direito Penal econômico: questões atuais. São Paulo: Revista dos Tribunais, 2011.

MAIA, Rodolfo Tigre. Dos crimes contra o sistema financeiro nacional: anotações à lei federal n. 7.492/86. São Paulo: Malheiros, 1999.

MALAN, Diogo. Bem jurídico tutelado pela Lei 7.492/1986. Revista Brasileira de Ciências Criminais, São Paulo, vol. 91, p. 367-392, jul./ago., 2011.

MARANHÃO, Douglas Bonaldi. Direito Penal Econômico e o bem jurídico protegido através do crime de evasão de divisas. Ciências Penais: Revista da Associação Brasileira de Professores de Ciências Penais, São Paulo, v. 8, n. 14, p.229-253, jan./jun., 2011.

MARTINS, Ives Granda da Silva. Princípio constitucional da liberdade de ir e vir com seus bens - Não recepção do $\int$ único do artigo 22 da Lei 7.492/86 pela Constituição de 88 - Outros aspectos jurídicos da saída com origem de moeda do país - Parecer. Revista Tributária e de Finanças Públicas, São Paulo, vol. 11, p. 135-143, abr./jun., 1995.

MASI, Carlo Velho. O crime de evasão de divisas na era da globalização: novas perspectivas dogmáticas, político-criminais e criminológicas. Porto Alegre: Pradense, 2013.

MEYER, Arno; MARQUES, Maria Silvia Bastos. A fuga de capital no Brasil: 1975/88. Pesquisa e Planejamento Econômico, Rio de Janeiro, v. 20, n, 1, p. 49-86, abr., 1990.

MOCCIA, Sergio. Emergência e defesa dos direitos fundamentais. Revista Brasileira de Ciências Criminais, São Paulo, v. 7, n. 25, p.58-91, jan./mar., 1999. 
MUZZI, Veridiane Santos. Evasão de divisas: aspectos sociológicos do crime. Revista Magister de Direito Penal e Processual Penal, Porto Alegre, v. 9, n. 50, p.46-51, out./nov., 2012.

NUNES, Ricardo Pieri. Evasão de divisas? Revista Brasileira de Ciências Criminais, São Paulo, v. 14, n. 62, p.134-177, set./out., 2006.

OLIVEIRA, Ana Carolina Carlos de. Hassemer e o direito penal brasileiro: direito de intervenção, sanção penal e administrativa. São Paulo: Instituto Brasileiro de Ciências Criminais, 2013

QUEIROZ, Rafael Mafei Rabelo O Direito a Ações Imorais: Paul Johann Anselm von Feuerbach e a construção do moderno direito penal. São Paulo: Almedina, 2012.

REALE JÚNIOR, Miguel. Despenalização no Direito Penal econômico: Uma terceira via entre o crime e a infração administrativa? Revista Brasileira de Ciências Criminais, São Paulo, vol. 28, p. 116-129, out./dez., 1999.

ROSA, Fábio Bittencourt da. Lei 7.492/86 e o concurso aparente de leis. Revista dos Tribunais, São Paulo, vol. 835, p. 467-472, mai., 2005.

. Evasão de divisas e lavagem de dinheiro. Revista da AJUFE, Brasília, v. 21, n. 70, p.183-188, abr./jun., 2002.

ROXIN, Claus. O conceito de bem jurídico crítico ao legislador em xeque. Revista dos Tribunais, São Paulo, vol. 922, p. 291-322, ago., 2012.

SANTOS, Gérson Pereira dos. Direito Penal Econômico. São Paulo: Saraiva, 1981, p.93/94

SCALCON, Raquel Lima. Doutrina do "direito e desenvolvimento" e a 
expansão do Direito Penal econômico no Brasil: reflexões a partir do crime de evasão de divisas. Revista Brasileira de Ciências Criminais, São Paulo, v. 22, n. 110, p.175-197, set./out., 2014.

SCHMIDT, Andrei Zenkner; FELDENS, Luciano. Limites normativos do delito de evasão de divisas: o ilícito administrativo como elemento pressuposto, porém insuficiente, à configuração do ilícito penal. In: FRANCO, Alberto Silva; LIRA, Rafael de Souza (Coord.). Direito Penal econômico: questões atuais. São Paulo: Revista dos Tribunais, 2011.

. O crime de evasão de divisas: a tutela penal do sistema financeiro nacional na perspectiva da política cambial brasileira. Rio de Janeiro: Lumen Juris, 2006.

. O delito de evasão de divisas 20 anos depois: sua redefinição típica em face das modificações da política cambial brasileira. In. ROCHA, João Carlos de Carvalho; HENRIQUES FILHO, Tarcísio Humberto Parreiras; CAZETTA, Ubiratan. Crimes contra o sistema financeiro nacional: 20 anos da Lei n. 7.492/1986. Belo Horizonte: Del Rey, 2006.

- Manutenção de depósitos no exterior e necessidade de sua declaração: considerações acerca do art. 22, parágrafo único, in fine, da lei n. 7.492/86. Boletim IBCCRIM, São Paulo, v. 13, n. 159, p.15-17, fev., 2006.

SCHÜNEMANN, Bernd. O Direito Penal é a ultima ratio da proteção de bens jurídicos! Sobre os limites invioláveis do Direito Penal em um estado de direito liberal. Revista Brasileira de Ciências Criminais, São Paulo, vol. 53, p. 9-37, mar./abr., 2005.

SILVA SÁNCHEZ, Jesús María. Teoría del delito y derecho penal económico. Revista Brasileira de Ciências Criminais, São Paulo, vol. 99, p. 327-356, nov./dez., 2012. 
- A expansão do Direito Penal: aspectos da política criminal nas sociedades pós-industriais. 3. ed. São Paulo: Revista dos Tribunais, 2013.

. La expansión del Derecho penal. Aspectos de la política criminal en las sociedades postindustriales. 2. ed. Madrid: Civitas, 1999.

SILVEIRA, Renato de Mello Jorge. A criminalização da evasão de divisas a questão do momento consumativo e a mudança de paradigmas. Revista de Direito Bancário e do Mercado de Capitais, São Paulo, v. 60, p. 261-271, abr./jun., 2013.

SOUZA, Luciano Anderson de. Evasão de divisas no projeto de código penal. Boletim IBCCRIM, São Paulo, v. 21, n. 243, p.5-6, fev., 2013.

STRECK, Lênio Luiz. Aplicar a letra da lei é uma atitude positivista? Novos Estudos Jurídicos, Itajaí, vol. 15, n. 1, p. 158-173, jan./abr., 2010.

SUTHERLAND, Edwin. Crime de colarinho branco: versão sem cortes. Tradução Clécio Lemos. Rio de Janeiro: Revan, 2015.

TAVARES, Juarez. Teoria do injusto penal. 3. ed. Belo Horizonte: Del Rey, 2003.

TÓRTIMA, José Carlos. Crimes contra o sistema financeiro nacional: Uma contribuição ao estudo da Lei $n^{\circ} 7.492 / 86$. 3. ed. Rio de Janeiro: Lumen Juris, 2011.

; TÓRTIMA, Fernanda Lara. Evasão de divisas: uma crítica ao conceito territorial de saída de divisas contido no parágrafo único do art. 22 da Lei 7.492. 3. ed. Rio de Janeiro: Lumen Juris, 2009. 